\title{
Using Images to Capture Faculty's Beliefs About Play and Learning in Early Childhood Education and Care Settings
}

\author{
Dr. Marleah Blom (Corresponding author) \\ Department of Education, Concordia University \\ 1455 De Maisonneuve Blvd. W., Montréal, Québec Canada, H3G 1M8 \\ Tel: (514) 848-2424 ext.7950Ｅ-mail: marleah@encs.concordia.ca
}

\author{
Dr. Miranda D’Amico \\ Department of Education, Concordia University
}

1455 De Maisonneuve Blvd. W., Montréal, Québec Canada, H3G 1M8

Tel: (514) 848-2424 ext. 2040 E-mail: Miranda.Damico@concordia.ca

Received: Oct. 13, 2016 Accepted: Nov. 13, 2016 Published: November 13, 2016

doi:10.5296/jse.v6i4.10151 URL: http://dx.doi.org/10.5296/jse.v6i4.10151

\begin{abstract}
Findings are presented from a qualitative research study that used photo-elicitation methods to explore faculty members' beliefs about play and learning for children in Early Childhood Education and Care environments when teaching preservice early childhood educators in recognized post-secondary Early Childhood Education programs in Canada. Participants believe that play is a vehicle for learning, advocate for children's free play in Early Childhood Education and Care settings as well as express concerns about the decline of play in children's lives. Implications of findings and the benefits of using images to elicit teacher beliefs in research will be discussed. Research on faculty members' beliefs is limited and findings come at an opportune time as advocacy for play in the early years is needed.
\end{abstract}

Keywords: Faculty beliefs, Early Childhood Education, Play, Learning, Photo-elicitation 


\section{Introduction}

Central to the life of a child is play (Johansson \& Samuelsson, 2006). Declared as a fundamental children's right and a developmental task of childhood, play is a central tenet in the lives of children (United Nations, 1989; Hewes, 2006). The relationship between play, learning and development has been documented without question in research, particularly for children (Howe, 2008; Miller \& Almon, 2009; Smith \& Pelligrini, 2008).

Despite its developmental benefits, literature within the past decade speaks to children being given less autonomy due to an emphasis on cognitive development, academic learning and school readiness. Free or child initiated play is 'under siege' (Hewes, 2006; Zigler \& Bishop-Josef, 2009). There are reported concerns that play is becoming 'institutionalized' in Early Childhood Education and Care (ECEC) environments, where more and more children are participating during their early years (Bushnik, 2006; Hewes, 2010; OECD, 2011).

Early childhood educators play a central role in ECEC settings given that they are responsible for creating activities and experiences for children's learning and growth on a daily basis (Friendly \& Prentice, 2009). Research has indicated that early childhood educators and teachers of young children believe in the importance of children's play yet there have been inconsistencies reported between their stated beliefs and their teaching practices, with implications for teacher education (Adams, 2005; Bennett, Wood, \& Rogers, 1997; Brett Valle-Riestra, Fischer, Rothlein, \& Hughes, 2002; Cheng, 2001; Cheng, 2012; Hewes, 2006; Kagan, 1992; Moyles, 2010; Parsons, 2013; Quance, Lehrer, \& Stathopoulos, 2008; Ranz-Smith, 2007; Vu, Han, \& Buell, 2012). "Both college classrooms and early childhood classrooms can be seen as play's conceptual fermenting grounds, and both can be places for respectfully and ethically synthesizing creative processes with content and skills" (Ranz-Smith, 2007, p. 99).

While education and training has been documented to positively influence the quality of ECEC environments (Ackerman, 2004; Arnett, 1989; Fukkink \& Lont, 2007; Kagan \& Newman, 1996; NICHD, 2006) as well as have an effect on educator practices (Enz \& Christie, 1997), the place of play in post-secondary Early Childhood Education programs, including details as to content, pedagogy and faculty's beliefs is however extremely limited, particularly in Canada. Children's play is reported to be at risk (Ryan \& Northey-Berg, 2014) and thus investigations into the beliefs and practices of those who help prepare upcoming early childhood educators within recognized post-secondary Early Childhood Education programs is warranted.

\section{Play and Learning in Early Childhood Education}

Within research and literature on play there has been a particular emphasis on its relationship with learning. This relationship is one that has been described as being reciprocal, complex and multidimensional (Hewes, 2006). While there is no consensus as to the precise nature and direction of the relationship itself, it has made significant contributions to theory, practice and policies in early childhood education.

Play has a longstanding history in ECEC environments (Wood \& Attfield, 2005). 
Philosophers dating back to Plato have discussed the place of play in the education of young children and various curricula have since been developed for early childhood education settings (Samuelsson \& Carlsson 2008; Samuelsson, Sharidan, \& Williams, 2006; Wolfe, 2002). Within each curricular approach to early childhood education, a certain relationship between play and learning is depicted and there is room for specific ways in which practitioners plan, organize, implement and assess their practices to reflect the relationship between play and learning. Practitioners, for example, can "...bring differing emphases on how much children play, which play is emphasized, and in what way the teacher is involved" (Wisneski \& Reifel, 2012, p. 178).

How play is implemented effectively for children's learning and development lies in the hands of early childhood educators, a term that encompasses titles such as childcare provider, child development worker, caregiver, and early childhood teacher. Believing in the value of play alone is not necessarily enough for early childhood educators to implement it within educational settings. "Creating environments where children can learn through play is not a simple thing to do consistently and well" (Hewes, 2006, p. 5). What they do may be dependent on their education and training.

\section{Play within Early Childhood Educators' Education and Training}

Education and training have been shown to have an effect on educator practices and linked to high quality environments (Arnett, 1989; Enz \& Christie, 1997; Fukkink \& Lont, 2007; NICHD, 2006; OECD, 2006; UNICEF, 2008). Essentially, educational programs consist of both theoretical and practical knowledge to help educators translate beliefs, philosophies and ideas into practice (Langford, 2008). To become advocates of play, early childhood educators require specific knowledge and dispositions to be able to articulate the value of play in children's lives as well as awareness of the role of play in their own lives as adults (Nicholson, Shimpi, \& Rabin, 2014).

While play and learning in early childhood education is well documented, how play and learning is viewed and implemented within higher education with adult learners is not understood or documented. College and university based Early Childhood Education programs are environments where adult learners can develop key understandings about play, both in theory and practice.

It is reported that in 2004, there were 135 post-secondary education settings that delivered Early Childhood Education certificate, diploma, degree and related programs in Canada (Beach \& Costigliola, 2004), with a majority of recognized programs housed within college settings. As Jacobs and Adrien (2012) point out, "typically, the content of these training programs is the result of 'best practice' information as interpreted by college instructors, and in some cases, the content is driven by provincial learning outcome mandates" (p. 124). Provincial and territory jurisdictions, each with their own subdivisions, are responsible for staff qualifications within the ECEC workforce as well as governing educational requirements. Within each post-secondary institution the faculty members play a key role in what is being taught to upcoming educators as well as how it is taught. 


\section{Faculty Members in Post-secondary Early Childhood Education Programs}

Just as an educator plays a central role in students' experiences in the early childhood classroom, it is the faculty member who acts as the decision maker who plans, organizes, implements and assesses at the teacher education level. As major players in the early childhood teacher education professional system (Horm, Hyson, \& Winton, 2013), teacher educators' teaching practices has been reported to influence what educators do in their own classrooms (Lunenberg, Korthagen, \& Swennen, 2007). This may include if and how they incorporate play. Information, however, about individuals who are responsible for educating the upcoming ECEC workforce is extremely limited, including their beliefs about play. Faculty and their beliefs are thus the focus of this study.

\section{Images and Photo-elicitation Research Methods}

Images and photo-elicitation methods were intentionally used to elicit and represent faculty's beliefs about play and learning. Inspired by arts based research, images were perceived to help promote new and alternative ways of knowing, thinking and representation, as well as to help elicit teaching beliefs, which have been documented to be difficult to uncover (Cole \& Knowles, 2008). For example, it has been voiced that individuals may not be aware of their beliefs or may not have the necessary vocabulary to express them (Kagan, 1992). Research indicates that beliefs are created and stored as images and thus language based retrieval methods are noted to not necessarily be compatible (Goodman, 1988; Pajares, 1992).

Photo-elicitation interviews (PEI) have been included within research in education (Ketelle, 2010), and early childhood education (Birkeland, 2013). They have been used to understand adult educators' beliefs (Taylor, 2002), preservice teachers' beliefs (Ruto-Korir \& Lubbe-De Beer, 2012; Stockall \& Davis, 2011), as well as preservice teachers' conceptions of the particular subject they teach (Seow, 2016). Photographs serve as symbols of meaning that people explain during the interview process. Photo-elicitation is a collaborative process that places an emphasis on individuals' personalized meanings, which are co-constructed in collaboration with the researcher (Birkeland, 2013; Clark-Ibáñez, 2004; Harper, 2002; Margolis, 2011; Pink, 2007, Richard \& Lahman, 2015). "In photo elicitation, this exchange is stimulated and guided by images" (Birkeland, 2013, p. 456).

Images can put participants at ease (Shulze, 2007), enhance rapport between the participant and the researcher, and provide active collaboration within both data collection and analysis (Clark-Ibáñez, 2004; Jenkings, Woodward, \& Winter, 2008). Images can empower participants (Richard \& Lahman, 2015) as well as provide structure to interviews and promote focus (Shulze, 2007; Stockall \& Davis, 2011). In photo-elicitation interviews both parties are anchored in an image that they explore together, revealing potentially different information than other methods.

Teacher beliefs have mainly been elicited through methods that include interviews, surveys, or written accounts. In line with qualitative research methods and data collection strategies suggested by those interested in exploring teacher beliefs (Fang, 1996; Kagan, 1992; Pajares, 1992), it was deemed that images within this study may encourage dialogue and collaboration 
with informants and could help gain access to faculty's thinking and tacit beliefs (Pajares, 1992). As Marland (1995) states, "implicit theories cannot be studied until they are first made explicit” (p. 133).

This study draws on data from a larger qualitative research study that explored faculty members' beliefs about play and learning and related teaching practices when educating preservice early childhood educators in recognized post-secondary Early Childhood Education diploma and certificate programs in Canada. A description of the methodology and findings specific to the following research question will be provided: What are faculty's beliefs about play and learning for children in ECEC settings?

\section{Methodology}

\section{Exploratory and Descriptive Design}

A qualitative, exploratory and descriptive design inspired by interpretative phenomenological analysis was created to be in alignment with the goals and research questions of the study. Interpretative phenomenological analysis (IPA) is a qualitative approach committed to exploring how people make sense out of their subjective experiences (Smith, Flowers, \& Larkin, 2009). It involves a double hermeneutic cycle in which a participant makes meaning of experience and the researcher then makes sense of the participant's meaning while acknowledging the active role of the researcher's knowledge, experience and conceptions as part of the process.

Founded in its main phenomenological, hermeneutic and idiographic theoretical roots, IPA honors individual's personal accounts and it places its attention on individual's stories prior to identifying group themes. With the potential for visual research tools to help elicit and express beliefs and tacit assumptions, images and photo-elicitation methods were used to help make each participating faculty member's meanings visible. Together with each participants' written responses and meanings elicited during the interviews, data was first triangulated to create individual cases. Aligned with the roots of IPA, all individual cases then provided the basis for a thematic analysis across the group to answer the main research question.

\section{Participants}

Names and contact information for recognized post-secondary Early Childhood Education programs across Canada were first gathered through government and institutional websites and 58 institutions were contacted to recruit faculty for the project. After adhering to numerous individual institutional ethics requirements participants were recruited for the study. Nineteen faculty members representing 13 institutions in six different Canadian provinces and territories volunteered to participate and completed the project.

All participants were female between 26 and 61 years at the time of data collection, with a mean age of 47.4 years. Sixteen participants (84\%) were between the ages of 40 and 59 years. The highest level of education held by participating faculty included a Diploma (5\%), a Bachelor degree (11\%), a Master's degree (73\%), or a combined Master's/Ph.D. degree (11\%) that was currently in progress. Most education programs were related to some form of Early 
Childhood Education or Child and Youth Studies while two participants reported having Master's degrees in areas related to adult learning.

Participating faculty all held a teaching position with six participants also indicating having a coordinator role within their respective institution. Participants reported a varied list of courses they had or were currently teaching with $26 \%$ reporting teaching courses where play was explicitly noted in the title.

All participants had experience working within the field of ECEC. Participants reported having worked directly with young children in roles such as support worker, educational assistant, educator, teacher, nanny, and camp counsellor or expressed having experience as consultants and administrators within early childhood education milieus. It was reported that faculty members worked anywhere between two and 36 years within post-secondary Early Childhood Education settings, with a majority (53\%) having taught between $0-10$ years, 26\% between 10-20 years, $16 \%$ between 20-30 years and 5\% between 30-40 years. The breakdown is comprised of total years teaching, including full time, part time and sessional work specific. Some participants indicated having had experience teaching in programs other than Early Childhood Education programs within post-secondary settings, which was not included.

\section{Data Collection and Analysis}

Participants were recruited, ethics approval was sought, and faculty members were asked to submit via e-mail written answers to demographic questions and a question about their beliefs on how children learn. They were also asked to select an image that they felt best depicted their beliefs about play and learning for children in ECEC settings to be sent to the first author prior to the interview. Images could come from multiple sources such as photographs, cartoons, paintings, and text as long as the image could be sent via e-mail to the interviewer prior to the first interview. Participants were informed that they could create their own images or images could be found elsewhere. It was requested that reference information for images be included, when applicable.

Data was reviewed and a one-hour photo-elicitation inspired interview was conducted with each participant. Depending on the geographical location, participants were given the choice to engage in the interview either in person, via telephone or Skype. After brief introductions, a summary of what would take place as well as addressing participants' questions, individuals were asked to talk about the image they had chosen to depict their beliefs about play and learning for children in ECEC settings.

To open up the conversation the interviewer, stated 'tell me about the picture'. Potential prompts were in place within the interview protocol, which included questions related to time, opportunity, access, space, materials or equipment, choice and initiative, as well as the adult or educator's role in children's play and learning in ECEC settings. Questions posed were contingent on the images and the information each participant shared. At the end of each interview the participant was asked if she had any additional comments. Interviews were recorded and transcribed by the first author. 
Data analysis involved reviewing each faculty members' information and writing notes in the author's journal during the research process. This contributed to the development of an overall coding framework, which included thematic categories such as (a) beliefs about how children learn, and (b) beliefs about play, including a definition, conditions, the educator's role, and the potential effects of play. Once all interviews were complete, observations on the types and contents of images submitted were noted. Data, including (a) written responses to questions about how children learn, (b) images and (c) photo elicitation interview transcripts for each individual were then triangulated to help promote a rich, trustworthy and holistic account of the information each individual shared.

A written summary of the author's understandings for each participant was created and sent for verification. Participants were asked to verify the information about their beliefs or make changes, if necessary. Verified data was then used to do a thematic analysis of beliefs about play and learning across the group. It was conducted based on three broad stages (Attride-Stirling, 2001). First, verified data from all participants was coded and reduced into meaningful segments based upon the thematic categories named within the coding framework. Data extracts for each category were explored in more detail to identify themes, which were created based on similar words, phrases and ideas voiced by participants. Themes were then integrated based on how they related to each other to answer the main research question. Interview transcripts were reread to ensure nothing was missed and that themes were accurately grounded within participant data. Commonalities among all 19 participants provide an overview as to what faculty's beliefs are on play and learning for children in ECEC settings.

\section{Findings}

\section{Types and Contents of Images}

Due to copyright, no images are provided. A total of 20 images were submitted by participants to depict their beliefs about play and learning for children in ECEC settings. Eighty five percent of all images included children of different ages, including infants, toddlers, and pre-adolescents. Children were perceived to be in similar age or mixed aged groups $(40 \%)$, pairs $(30 \%)$, or alone $(30 \%)$. Adults were present in $30 \%$ of the images that included children. Adults were off to the side watching or were engaging with children (e.g. smiling, making silly faces, sharing, stimulating with materials).

All images except for three demonstrated children visibly engaged in a physical act. Visible actions include jumping, splashing, looking, touching, digging, crawling, riding, climbing, balancing, building, painting, feeling, measuring, moving, opening or closing, making, manipulating, and concentrating. While not all images showed people's faces, no one in the images came across as sad or angry through their faces or body language. No one was visibly talking.

Images depicted some form of outdoor (60\%) or indoor (30\%) environment while $10 \%$ of the images were displayed on a blank background. Indoor environments appeared to include classrooms or home settings. Materials in the environments included such items as natural 
materials (leaves, dirt, puddles, tree branches, gardens, rocks, car tires, and a ladybug), art materials (cardboard boxes, paper, ribbons, shovels, paints, wrench and tools, measuring tape, and goop), or toys (bike, sword, cups, train, fireman hats, doll houses, cars, and blocks). Outdoor playground type equipment were present in two images.

\section{Faculty Beliefs: Play and Learning for Children in ECEC Settings}

Within written responses to how children learn, faculty members reported children as being naturally curious, trusting, spontaneous, willing, accommodating, and open to learning. Children as learners were noted to be willing to engage in experiences and enjoy figuring things out. It was reported that children learn through physical interactions with materials, people and their real environments. Terms such as active, hands on, manipulating, doing, exploring, experimentation, questioning, whole body, senses, discovery, and inquiry were used. It was also explicitly stated by $79 \%$ of the participants "children learn through play." As one faculty member wrote, "that's how children learn, they are playing."

Overall, a play and learning relationship was conceptualized when participants were talking about how children learn. Data from photo-elicitation interview transcripts revealed that conversations about the images participants submitted to best depict their beliefs about play and learning for children in ECEC extended upon this perceived relationship. For example, when talking about her image, a participant stated, "in the case of young children's play, that's where, that you know, wonderful learning can happen. It does happen."

During the interviews, support for the value of play as a tool, vehicle or medium for learning in ECEC settings was consistently reported. It was stated how "play is the beginning of everything. We have no childhood without play," and another expressed "I see the value of allowing children to play and that they are learning." Through play, children were described as making concrete gains in development within various domains. Play was discussed in terms of how it allows children to take ownership, feel competent as well as help them figure out what is happening in their lives.

While no unified definition of play was provided across the group within the photo-elicitation interviews, further details about what play is, the role of the early childhood educator and environments within the context of play and learning in ECEC settings were provided. Terms participants used when describing play in their images were reviewed and key characteristics were identified, which include (a) active engagement, (b) freedom, (c) positive affect, as well as (d) wonder and curiosity.

Active Engagement

Play was voiced to encompass active engagement, including the body and senses. A participant stated "for me play is engagement," while another stated that play is "just getting right in there." As indicated above, $85 \%$ of the content of the images received illustrated children engaged in some form of physical engagement. For example, there was an image of children of various ages actively immersing themselves with their full bodies in a pile of leaves, an image of children and adults interacting with materials and another that denoted a child concentrating on watching a ladybug on her hand. 
Freedom

Faculty members strongly advocated for free play in ECEC environments, where children are provided opportunities to take the lead and actively interact within safe environments that meet their interests and needs. Freedom in play was depicted from the terms used during the interviews that implied self-direction, openness, spontaneity, choice, and doing what the individual wants. "I think my definition of play is that it isn't controlled by someone else." A messiness and lack of structure was described as well as illustrated in an image of two children jumping into a mud puddle. Other images included garden landscapes, which were described in terms of freedom and possibilities. Only six of the images submitted to depict faculty's beliefs about play and learning for children included adults. Adults who were present in the images did not appear to be taking over the children's play. In discussing her image, for example, one participant said, "I didn't want the adult to be there just because I felt that we can be there, we can guide, we can give all that we can give but then we need to step back."

"Sometimes adults just mess too much with children's play. They want it to be all about learning or they want it want it to be too safe or structured or they just take over." The notion of letting the child lead and experiment freely was discussed and supported by the images submitted and participants expressed clear concerns about the decline of children's free play for the sake of adult driven outcomes, predetermined goals and tight schedules in educational settings. Within the interview protocol, there were no questions aimed to generate information specific to participants concerns about children's play yet participants expressed concerns about the decline of both children's play and the implementation of play-based learning in education. Numerous participants voiced that there is an apparent lack of freedom in both children's play and playground activity. They also expressed that children are overprotected.

Concerns were raised in terms of educators being focused on predetermined goals and preparing children for academics. Participants expressed how social expectations and pressures are being downloaded onto children and that there are attempts to fit children into boxes. "I think when the teacher has to spend more time telling children what to do instead of listening to what the children are saying or doing, or watching what they are doing, then you have a problem." It was expressed how there is a focus on assessment and adult derived outcomes. Participants disagreed that worksheets and activities with set end goals should be referred to as play-based approaches in education settings.

\section{Positive Affect}

Play as described as "fun." It was commonly discussed as being happy and joyful or something that people enjoy, for example "when I think of play I think of happiness." Images did not illustrate negative emotions. One image was a video of a young child laughing as an adult rips a piece of paper.

Wonder and Curiosity

Participants noted that play involves, awe, wonder and curiosity and transcripts revealed that 
play was associated with terms such as exploration, experimentation, inquiry, problem solving and imagination. For example, one participant, when discussing her image of two children peeking through tires, reported that "play as the learning tool means self-discovery, exploration, experimentation, curiosity, supported independent problem-solving, and initiative."

\section{Early Childhood Educators and Play Spaces}

Participants believe that early childhood educators are models for children and parents. In addition to educators (a) ensuring that children's basic needs are met, (b) allowing time for children to play, and (c) providing permission for freedom within play, the need to provide appropriate materials for children's play and learning was expressed. It was suggested that when working with children, a variety of materials that allow a multitude of possibilities should be provided, materials should be changed regularly and materials should be carefully selected based on children's individual needs and interests. The importance of the outdoors, natural environment and materials were reported by many to be important elements to include for play and learning with children. Over half of the images depicted outdoor spaces. A participant indicated that play and learning is:

...perhaps easier in the outdoors. Maybe that environment encourages it more. There's no rules, or boundaries about the materials out there... so the children have more freedom, or the adults have more freedom. It's literally open, like the sky is literally the limit cause there is no ceiling.

\section{Discussion}

Within the landscape of early childhood education and care, faculty members play an influential role in helping shape the place of play in young children's learning and development by educating upcoming preservice educators in post-secondary environments. Information as to who faculty are and what they believe, however, has been overlooked. It is acknowledged that data for the study was self-reports, 19 faculty members self-selected to participate and these participants represented only a small fraction of faculty members within the large Canadian landscape. Future research may involve faculty and trainers from a variety of contexts to share their stories.

Participants' insights within this study were unique to their own respective experiences. Generalization cannot be made yet findings contribute to understandings about faculty's beliefs about play and learning within a Canadian context as well as encourage continued research in the area. Supporting faculty to engage in continuous reflection about their own beliefs about play and learning may also contribute to faculty members embracing their role as advocates for play along with demonstrating and speaking to the value of play and learning within their practices with adult learners.

Many of the findings reflect how faculty members' beliefs are similar to those reviewed within the literature. No unified definition of play was provided across the group of participants, yet identified characteristics were similar to those used to define play, including positive affect, active engagement, freedom from external rules, and attention to process 
rather than product (Krasnor \& Pepler, 1980; Rubin, Fein, \& Vandenberg, 1983). Through the collection of images the study also revealed that children's play and learning could be represented in various ways. Considering "not all play is learning and not all learning is play" (Hewes, 2006, p. 5) and "there is no one definition of play and there is no one right way of enacting a pedagogy of play" (Ryan \& Northey-Berg, 2014, p. 212), findings support the many meanings of play as well as how play and learning in practice within educational settings can be a complex matter.

The study revealed that participating faculty believe in the value of play for children in ECEC settings, particularly free play, and the role of play in children's learning. Faculty's reported concerns for children's play are similar to those that have been previously documented, including how children are becoming 'hurried' (Elkind, 2007), how 'helicopter parents' (Howe, 2008) are putting their children in more and more structured activities, and how there is a push for academic learning to replace play in the classroom (Patte, 2012; Ranz-Smith, 2007; Vu, Han, \& Buell, 2012; Wood \& Attfield, 2005), where academic learning is seen as incongruent with play (Nicholson, Shimpi, \& Rabin, 2014). These concerns as well as reported benefits of play for learning in this study, support the need for continued advocacy for free play as well as the inclusion of play content and pedagogy in post-secondary programs, particularly now that play is reportedly at risk.

By uncovering faculty's beliefs and ways in which play is implemented for adult learning, findings support the need for early childhood educators to learn more as to the value of child initiated play and understanding play's relationship with learning. The study also promotes the need for educators to become aware of play in their own adult lives as well as be comfortable with play in order to implement it with children and articulate the benefits of play to others.

\section{Conclusion}

To provide positive experiences for children in ECEC settings, early childhood educators need quality education themselves. Post-secondary Early Childhood Education programs can be a fruitful venue for preservice early childhood educators to engage in reflection. Future research and reflections may centre on how faculty members model free play and provide meaningful and embodied play experiences for adult learning through their teaching practices in post-secondary classrooms.

Through the use of images and photo-elicitation methods, this study introduces a unique approach to study beliefs about play. While it is impossible to determine its effectiveness compared to other methods used to elicit beliefs, this particular approach embraces multiple ways of knowing, creating and representing data. Images themselves provided a different form of representation as compared to written or verbal data. When triangulating participants' written responses, image content and interview transcripts, it is possible to obtain a richer picture of participants' views, take into account complexities, as well as observe potential contradictions.

Participants' individualized meanings are emphasized through the selection and discussion of 
images. By having participants choose their own images as compared to having a selection of images for participants to choose from, the interviewer was invited into the worldview of the participant specific to their beliefs about play and learning in a way that best suited the individual. Through photo-elicitation, both the interviewer and participant were able to collaborate on an externalized version of an otherwise tacit assumption as meanings were made visible. While the use of images enabled externalizing participants' tacit assumptions, the use of the method revealed various considerations.

During the photo-elicitation interviews, participants made a few comments specific to the selection of images. "I had some difficulty selecting a photo that symbolized my thoughts about play." The process was deemed time consuming by some and difficulties were expressed in terms of finding images that encompassed everything they wanted to show. It is thus suggested to include questions about what is not in the images during photo-elicitation interviews. Issues with copyright and identity protection can also hamper utilizing images to represent and disseminate data and findings. Despite possible limitations and considerations, the method was valuable in helping answer the research questions for this particular study and has potential for continued explorations in capturing teachers' beliefs.

\section{Acknowledgements}

The study would not have been possible without the Early Childhood Education faculty members across Canada who took the time to share their stories.

\section{References}

Adams, S. (2005). Practitioners and play: Reflecting in a different way. In J. Moyles (Ed.), The excellence of play ( $2^{\text {nd }}$ ed., pp. 213-227). Berkshire, England: Open University Press.

Ackerman, D. J. (2004). States' efforts in improving the qualifications of early care and education teachers. Educational Policy, 18(2), 311-337. http://dx.doi.org/10.1177/0895904803262145

Arnett, J. (1989). Caregivers in day care centers: Does training matter? Journal of Applied Developmental Psychology, 10, 541-552. http://dx.doi.org/10.1016/0193-3973(89)90026-9

Attride-Stirling, J. (2001). Thematic networks: an analytic tool for qualitative research. Qualitative research, 1(3), 385-405. https://doi.org/10.1177/146879410100100307

Beach, J., \& Costigliola, B. (2004). Working for change: Canada's child care workforce: executive summary. Ottawa, ON: Child Care Human Resources Sector Council.

Bennett, N., Wood, L., \& Rogers, S. (1997). Teaching through play: Teachers' thinking and classroom practice. Buckingham, UK: Open University Press.

Birkeland, Å. (2013). Research dilemmas associated with photo elicitation in comparative early childhood education research. Research in Comparative and International Education, 8(4), 455-467. http://dx.doi.org/10.2304/rcie.2013.8.4.455

Brett, A., Valle-Riestra, D. M., Fischer, M., Rothlein, L., \& Hughes M. T. (2002). Play in 
preschool classrooms: Perceptions of teachers and children. Journal of Early Childhood Teacher Education, 23(1), 71-79. http://dx.doi.org/10.1080/1090102020230112

Bushnik, T. (2006). Child care in Canada (Children and Youth Research Paper Series No. 003). Ottawa, Ontario: Statistics Canada.

Byington, T. A., \& Tannock, M. T. (2011). Professional development needs and interests of early childhood education trainers. Early Childhood Research and Practice, 13(2). Retrieved from http://ecrp.uiuc.edu/v13n2/byington.html

Cheng, D. P. (2001). Difficulties of Hong Kong teachers' understanding and implementation of 'play' in the curriculum. Teaching and Teacher Education, 17(7), 857-869. http://dx.doi.org/10.1016/S0742-051X(01)00035-X

Cheng, D. P. (2012). The relation between early childhood teachers' conceptualization of "play" and their practice: Implication for the process of learning to teach. Frontiers of Education in China, 7(1), 65-84.

Clark-Ibáñez, M. (2004). Framing the social world through photo-elicitation interviews. American Behavioral Scientist, 47(12), 1507-1527. http://dx.doi.org/10.1177/00027642042 66236

Cole, A. L., \& Knowles, J. G. (2008). Arts-informed research. In J. G. Knowles \& A. L. Cole (Eds.), Handbook of the arts in qualitative research: Perspectives, methodologies, examples, and issues (pp. 55-70). Los Angeles, CA: Sage Publishing. http://dx.doi.org/10.4135/9781452 226545.n5

Elkind, D. (2007). The power of play: How spontaneous imaginative activities lead to happier, healthier children. Cambridge, MA: Da Capo Press.

Enz, B., \& Christie J. (1997). Teacher play interaction styles: Effects on play behavior and relationships with teacher training and experience. International Journal of Early Childhood Education, 2, 55-69.

Fang, Z. (1996). A review of research on teacher beliefs and practices. Educational Researcher, 38(1), 47-65. http://dx.doi.org/10.1080/0013188960380104

Friendly, M., \& Prentice, S. (2009). About Canada childcare. Halifax, NS: Fernwood.

Frost, J. L., Wortham, S. C., \& Reifel, S. (2012). Play and child development (4 ${ }^{\text {th }}$ ed.). Upper Saddle River, NJ: Pearson Education, Inc.

Fukkink, R., \& Lont, A. (2007). Does training matter? A meta-analysis and review of caregiver training studies. Early Childhood Research Quarterly, 22, 294-311. http://dx.doi.org/10.1016/j.ecresq.2007.04.005

Goodman, J. (1988). Constructing a practical philosophy of teaching: a study of preservice teachers' professional perspectives. Teaching and Teacher Education, 4, 121-137. http://dx.doi.org/10.1016/0742-051X(88)90013-3 
Harper, D. (2002): Talking about pictures: A case for photo elicitation, Visual Studies, 17(1), 13-26. http://dx.doi.org/10.1080/14725860220137345

Hewes, J. (2006). Let the children play: Nature's answer to early learning. Montreal: Early Childhood Learning Knowledge Center, Canadian Council on Learning.

Hewes, J. (2010). Learning through play: A view from the field. In R. E. Tremblay, R. G. Barr, R. DeV. Peters R., \& M. Boivin (Eds.), Encyclopedia on early childhood development Montreal, Québec: Centre of Excellence for Early Childhood Development. Retrieved from http://www.child-encyclopedia.com/sites/default/files/docs/ perspectives/hewesangps.pdf

Horm, D. M., Hyson, M., \& Winton, P. J. (2013). Research on early childhood teacher education: Evidence from three domains and recommendations for moving forward. Journal of Early Childhood Teacher Education, 34(1), 95-112. http://dx.doi.org/10.1080/10901027.

2013.758541

Howe, N. (2008). Commentary on Smith and Pellegrini and Hirsh-Pasek and Golinkoff. In R. E. Tremblay, R. G. Barr, R. DeV. Peters R., \& M. Boivin, (Eds.), Encyclopedia on early childhood development. Montréal, Québec: Centre of Excellence for Early Childhood Development. Retrieved from http://www.child-encyclopedia.com/documents/HoweANGxp. pdf

Howes, C. Phillips, D.A., \& Whitebook, M. (1992). Teacher characteristics and effective teaching in child care: Findings from the National Child Care Staffing Study. Child \& Youth Care Forum, 21(6), 399-414. http://dx.doi.org/10.1007/BF00757371

Jacobs, E., \& Adrien, E. (2012). Canadian child care regulations regarding training and curriculum. In N. Howe \& L. Prochner (Eds.), Recent perspectives on early childhood education and care in Canada (pp. 109-146). Toronto, ON: University of Toronto Press.

Jenkings, N. K., Woodward, R., \& Winter, T. (2008). The emergent production of analysis in photo elicitation: Pictures of military identity. Forum Qualitative Sozialforschung/Forum: Qualitative Social Research, 9(3). Retrieved from http://www.qualitative-research.net/index. $\mathrm{php} /$ fqs/article/view/1169/2590

Johansson, E., \& Samuelsson, I., (2006). Play and learning-inseparable dimensions in preschool practice. Early Child Development \& Care, 176(1), 47-65. http://dx.doi.org/10.1080/0300443042000302654

Kagan, D. (1992). Implications of research on teacher belief. Educational Psychologist, 27(1), 65-90. http://dx.doi.org/10.1207/s15326985ep2701_6

Kagan, S. L., \& Neuman, M. J. (1996). The relationship between staff education and training and quality in child care programs. Child Care Information Exchange, 56-69.

Kettle, D. (2010). The ground they walk on: Photography and narrative inquiry The Qualitative Report, 15(3), 547-568.

Krasnor, L. R., \& Pepler, D. J. (1980). The study of children's play: Some suggested future 
directions. In K. H. Rubin, (Ed.), Children's play: New directions for child development (pp. 85-95). Jossey-Bass Inc. http://dx.doi.org/10.1002/cd.23219800908

Langford, R. (2008). Making a difference in the lives of young children: A critical analysis of a pedagogical discourse for motivating young women to become early childhood educators. Canadian Journal of Education, 31(1), 78-101.

Lunenberg, M., Korthagen, F., \& Swennen, A. (2007). The teacher educator as a role model. Teaching and Teacher Education, 23, 586-601. http://dx.doi.org/10.1016/j.tate.2006.11.001

Margolis, E., \& Pauwels, L. (Eds.). (2011). The Sage handbook of visual research methods. London: Sage. http://dx.doi.org/10.4135/9781446268278

Marland, P. W. (1995). Implicit theories of teaching. International encyclopedia of teaching and teacher education, 1(2), 15-23.

Miller, E., \& Almon, J. (2009). Crisis in the kindergarten: Why children need to play in school. The Educational Digest, 75, 42-45.

Moyles, J. (Ed.). (2010). The excellence of play ( $3^{\text {rd }}$ ed.). Berkshire: Open University Press.

National Institute of Child Health and Human Development (NICHD) Early Child Care Research Network. (2006). Characteristics of infant child care: Factors contributing to positive caregiving. Early Childhood Research Quarterly, 11(3), 269-306.

Nicholson, J., Shimpi, P. M., \& Rabin, C. (2014). If I am not doing my own playing then I am not able to truly share the gift of play with children: Using poststructuralism and care ethics to examine future early childhood educators' relationships with play in adulthood. Early Child Development and Care, 184(8), 1192-1210. http://dx.doi.org/10.1080/03004430.2013. 856894

Nicholson, J., Shimpi, P. M., Kurnik, J., Carducci, C., \& Jevgjovikj, M. (2014). Listening to children's perspectives on play across the lifespan: Children's right to inform adults' discussions of contemporary play. International Journal of Play, 3(2), 136-156. http://dx.doi.org/10.1080/21594937.2014.937963

Organization for Economic Development and Co-operation (2006) Starting Strong II: Early childhood education and care. Paris: OECD.

Organisation for Economic Co-operation and Development (2011). Education at a glance 2011: OECD indicators. Paris: OECD.

Pajares, M. F. (1992). Teachers' beliefs and educational research: Cleaning up a messy construct. Review of Educational Research, 62(3), 307-332. http://dx.doi.org/10.3102/003 46543062003307

Parsons, A. L. (2013). Early childhood educators' constructions of play beliefs and practice. (Unpublished doctoral dissertation). University of Ottawa: Ottawa, ON.

Patte, M. (2012). Implementing a playful pedagogy in a standards-driven curriculum: 
Rationale for action research in teacher education. In L. E. Cohen \& S. Waite-Stupiansky (Eds.), Play: A polyphony of research, theories, and issues: Play and culture studies, Vol. 12 (pp. 67-89). Lanham, MD: University Press of America.

Pink, S. (2007). Applied visual anthropology: Social intervention, visual methodologies and anthropological theory. New York: Berghahn Books.

Quance, A., Lehrer, J. S., \& Stathopoulos, H. (2008). Play in the grade one classroom: An exploration of teacher beliefs, classroom organization, and obstacles to implementation in Québec. Canadian Journal for New Scholars in Education, 1(1), 1-18.

Ranz-Smith, D. J. (2007). Teacher perception of play: In leaving no child behind are teachers leaving childhood behind? Early Education \& Development, 18(2), 271-303. http://dx.doi.org/10.1080/10409280701280425

Richard, M., \& Lahman, K. E. (2006). Photo-elicitation: reflexivity on method, analysis, and graphic portraits. International Journal of Research \& Method in Education, 38(1), 3-22. https://doi.org/10.1080/1743727X.2013.843073

Rubin, K. H. (1982). Early play theories revisited: Contributions to contemporary research and theory. In D. J. Pepler \& K. H. Rubin (Eds.), The play of children: Current theory and research (Vol. 6, pp. 4-14). New York: Karger. http://dx.doi.org/10.1159/000407155

Ruto-Korir, R., \& Beer, L. D. (2012). The potential for using visual elicitation in understanding preschool teachers' beliefs of appropriate educational practices. South African Journal of Education, 32(4), 393-405. http://dx.doi.org/10.15700/saje.v32n4a661

Ryan, S., \& Northey-Berg, K. (2014). Professional preparation for a pedagogy of play. In L. Brooker, M. Blaise \& S. Edwards (Eds.) The Sage handbook of play and learning in early childhood (pp. 204-215). Los Angeles, CA: Sage. http://dx.doi.org/10.4135/9781473907850. n20

Samuelsson, I. P., \& Carlsson, M. A. (2008). The playing learning child: Towards a pedagogy of early childhood. Scandinavian Journal of Educational Research, 52(6), 623-641. http://dx.doi.org/10.1080/00313830802497265

Samuelsson, I. P., Sharidan, S., \& Williams, P. (2006). Five preschool curricula: Comparative perspective. International Journal of Early Childhood, 38(1), 11-30. http://dx.doi.org/10.1007/BF03165975

Seow, T. (2016). Reconciling discourse about geography and teaching geography: The case of Singapore pre-service teachers. International Research in Geographical and Environmental Education, 25(2), 151-165. http://dx.doi.org/10.1080/10382046.2016.1149342

Schulze, S. (2007). The usefulness of reflexive photography for qualitative research: A case study in higher education. South African journal of higher education, 21(5), 536-553.

Singer, D., Golinkoff, R. M., \& Hirsh-Pasek, K. (Eds.) (2011). Play=Learning: How play motivates and enhances children's cognitive and social-emotional growth. New York, NY: 
Oxford University Press.

Smith, J. A., Flowers, P., \& Larkin, M. (2009). Interpretative phenomenological analysis: Theory, method and research. London: Sage.

Stockall, N., \& Davis, S. (2011). Uncovering pre-service teacher beliefs about young children: A photographic elicitation methodology. Issues in Educational Research, 21(2), 192-209.

Taylor, E. W. (2002). Using still photography in making meaning of adult educators' teaching beliefs. Studies in the Education of Adults, 34(2), 123-139. http://dx.doi.org/10.1080/02660 830.2002 .11661466

UNICEF. (2008). The child care transition: A league table of early childhood education and care in economically advanced countries (Innocenti Report Card 8). Florence: UNICEF Innocenti Research Centre.

United Nations. (1989). Convention on the Rights of the Child. New York: United Nations.

van Leeuwen, L., \& Diane Westwood, D. (2008). Adult play, psychology and design. Digital Creativity, 19(3), 153-161. http://dx.doi.org/10.1080/14626260802312665

Vu, J. A., Han, M., \& Buell, M. J. (2012). Preserving play in early childhood classrooms: Suggestions for early childhood teacher education and policy. In L. E. Cohen \& S. Waite-Stupiansky (Eds.), Play A polyphony of research, theories, and issues: Play and culture studies, Vol 12 (pp. 207-221). Lanham, MD: University Press of America.

Wisneski, D. B., \& Reifel, S. (2012). The place of play in early childhood curriculum. In N. File, J. J. Mueller, \& D. B. Wisneski (Eds.), Curriculum in early childhood education: Re-examined, rediscovered, renewed (pp. 175-187). New York: Routledge.

Wolfe, J. (2002). Learning from the past: Historical voices in early childhood education (2nd ed.). Mayerthorpe, AB: Piney Branch Press.

Wood, E. (2008). Everyday play activities as therapeutic and pedagogical encounters. European Journal of Psychotherapy and Counselling, 10(2), 111-120. http://dx.doi.org/10.1080/13642530802076151

Wood, E. A. (2014). The play-pedagogy interface in contemporary debates. In L. Brooker, M. Blaise, \& S. Edwards (Eds.), The Sage handbook of play and learning in early childhood (pp. 145-156). Los Angeles, CA: Sage. http://dx.doi.org/10.4135/9781473907850.n15

Wood, E., \& Attfield, J. (2005). Play, learning and the early childhood curriculum (2 ${ }^{\text {nd }}$ ed.). London: Paul Chapman. http://dx.doi.org/10.4135/9781446280393

Zigler, E. F., \& Bishop-Josef, S. J. (2009). Play under siege: A historical overview. Zero to three, 30(1), 4-11. 